\title{
RESEARCH
}

\section{Post-merger Effect on Operating Performance of Financial Institutions: Evidence from Nepal}

\section{Hari Prasad Pathak}

ABSTRACT

\section{KEY WORDS}

Merger

Operating Performance

Profitability

Accounting Ratios
This article studies post-merger operating performance of financial institutions using the data set published in their annual reports. Based on 22 merger deals made during 2004-20013 by financial institutions listed in the Nepal Stock Exchange, this paper analyzes their financial statements for four years (two year before the merger and two year after the merger) by using six key accounting ratios. In spite of certain limitations, accounting ratios are still considered as a convenient and reliable analytical tool. The article concludes that merger deals fail to significantly improve the post-merger operating performance of financial institutions.

ONE OF THE PERCEIVED MEANS for value creation in business is through growth (Osae, 2010). Ramani (2012) asserts that firms could grow internally either through the process of introducing new products or by enlarging the capacity of the existing products. The growth process can be facilitated externally by mergers and acquisitions. Mergers mean any transaction that forms one economic unit from two or more previous ones (Copeland, Weston, Shastri, \& Katz, 2011). A merger usually results in a new company name, often the combination of both original companies into a new brand (Osae, 2010). The merger decision is a portfolio diversification and external growth decision aiming to gain competitive advantage through synergy by combining activities of two or more companies. Such actions are commonly voluntary and involve stock swapping and/or cash payment to the target. In some countries like Germany, weak banks are forcefully merged to avoid the problem of financial distress arising out of bad loans and erosion of capital funds (Jayadev \& Sensarma, 2007). The motives behind such merger is "too big to fail" principle followed by the regulatory authorities.

Merger and acquisition is not a new phenomenon in the international context -though it entered recently in the Nepalese economy. The banking industry has undergone rapid consolidation in last few years. Globalization, technological advancement, and deregulation have stimulated more banks to go for merger (Kwan \& Wilcox, 1999). Mergers may reduce costs if they 
enable banks to close redundant branches or consolidate back-office functions. Mergers may make banks more productive if they increase the range of products that banks can profitably offer. They may also diversify further bank portfolios and thereby reduce the probability of insolvency. Increased diversification may reduce banks' total costs by reducing desired capital-asset ratios. Thus, mergers and acquisitions in banking sector have become popular as a major way of corporate restructuring in the majority of all the countries in the world (Jayadev \& Sensarma, 2007).

Dobbs, Goedhart, and Sunio (2006) study showed that value was destroyed by mergers during 1995 and 2000 while mergers that occurred during 2003 and 2006 were able to create value. DePamphilis (2008) indicated that the majority of mergers and acquisitions underperform the industry average. In line with many researchers, Berger and Humphrey (1997) and Liu and Tripe (2001) noted that there was no evidence of positive impact on performance of firms in the mergers and acquisitions activities.

In Nepal merger is still a new practice, and therefore, has not received importance yet. This paper attempts to empirically examine the postmerger operating performance of Nepalese financial institutions.

The remainder of this article is structured as follows. Section I reviews related studies on announcement effect of mergers and acquisitions. Section II describes the data and methodology, while Section III presents the results and discussion. Section IV offers summary and conclusion.

\section{Related Studies}

Merger involves two or more fairly equal companies, which combines to become one legal entity that is worth more than their separate parts (Coyle, 2000). The shareholders of all pre-merger firms have a share in the possessions of the merged firm and the senior management of pre-merger firms will continue to hold management positions after the merger. Mergers and acquisitions are one of the ways by which firms attempt to create value. The reasons for such activity often include, among others, expansion into new markets, acquisition of cutting edge technology, achieving economies of scale, reduction of duplicate costs and reduction of competition (DePamphilis, 2008).

There are three general ways of mergers. A vertical merger takes place between the companies operating in the same industry. Motives for such mergers could be several, but usually the acquiring company chooses to implement a vertical merger in order to establish control of the whole production chain, thus potentially securing and strengthening its market position. Merger between an airline company and a travel agency is an example of vertical merger. By doing so, the airline company prevents the possibility for the travel agency to change airline in the future, as well as improving and developing its marketing strategy, which could be for instance marketing of travel and flights to destinations where the airline has the most available flights (Weston, Mitchel \& Mulherin, 2004).

A merger occurring between companies which are operating and competing in the same industry is known as horizontal merger. One of the motives of horizontal merger is to seek advantages in economics of scale by improving the management and administration of the company.

A merger between firms that are involved in totally unrelated business activities is called conglomerate 
merger. This type of mergers are often made with the purpose of diversifying one's risks, and are often performed by companies which have their core businesses in a relatively high risk type on industry (Weston, Mitchel \& Mulherin, 2004).

The terms merger and acquisition are often confused or used interchangeably (Sherman \& Hart, 2006). Although merger and acquisition are often used as synonymous terms, there is a subtle difference between the two concepts. When one company takes over another and clearly established itself as the new owner, the purchase is called an acquisition. From a legal point of view, the target company ceases to exist, the buyer swallows the business and the buyer's stock continues to be traded. A merger happens when two firms, often of about the same size, agree to go forward as a single new company rather than remain separately owned and operated. This kind of action is more precisely referred to as a "merger of equals." Both companies' stocks are surrendered and new company stock is issued in its place. In practice, however, actual mergers of equals do not happen very often. Usually, one company will buy another and, as part of the deal's terms, simply allow the acquired firm to proclaim that the action is a merger of equals, even if it is technically an acquisition. Being bought out often carries negative connotations, therefore, by describing the deal as a merger, deal makers and top managers try to make the takeover more palatable.

In the Nepalese economy, merger, in the real sense, was started only in April 2004 with the merger between Laxmi Bank and HISEF Finance. Merger By-law was later enacted in 2012 (2068 B.S.). On the acquisition front, Butwal Power Company acquired Khimti and Bhotekoshi Hydropower companies. Standard Chartered Bank acquired Grindlays Bank from the ANZ Group (Nepal Economic Forum, 2010). Similarly, Teliasonera acquired Spice Nepal to form NCell (Nepal Economic Forum, 2010). All these acquisitions have occurred before promulgating the Acquisition Bylaw 2014 by Nepal Rastra Bank. After passing the Acquisition By-law in 2014 (2070 B.S.), financial institutes have started acquiring other financial institutions. Recently Citizen Bank International acquired Nepal Housing and Merchant Finance Ltd. and People Finance Ltd. Similarly, Muktinath Bikas Bank acquired Civic Development Bank.

Operating performance studies attempt to identify the sources of gains from mergers and to determine whether the expected gains at announcement are ever actually realized. Such studies generally examine the changes in financial performance, which are based on pre- and post- merger accounting data of the target and the acquirer or the newly combined firm. More specifically, the changes of net income, profit margin, growth rates, return on equity (ROE), and return on asset (ROA) and liquidity of the firm are the focus of accounting studies (Bruner, 2002; Pilloff, 1996).

Healy, Palepu, and Ruback (1992) examined postmerger operating performance for the 50 largest mergers between 1979 and 1984. They found that merged firms experience improvements in asset productivity, leading to higher operating cash flows relative to their industry peers. Interestingly, their results showed that the operating cash flows of merged firms actually drop from their pre-merger level on average, but that the non-merging firms in the same industry drop considerably more. Thus, the post-merger operating performance improves relatively to the industry benchmark. 
A study made by Avkiran (1999), measured relative efficiency gains for Australian banks for the period of 1986-1995, using data envelopment analysis (DEA) and financial ratios. He used the intermediations approach and two DEA models: A and B. Model A includes interest expense and noninterest expense as inputs and net interest income and non-interest income as outputs; while Model B includes deposits and staff numbers as inputs and net loans and non-interest income as outputs. He found that acquiring banks do not always maintain their pre-merger efficiency. Liu and Tripe (2001) used accounting ratios and DEA to explore the efficiency impact of six bank mergers in New Zealand between 1989 and 1998 and found that in a majority of cases the merger led to an increase in efficiency.

The review of literature shows mix results regarding operating performance of acquirer. For example, studies by Cornett and Tehranian (1992) and Spindt and Tarhan (1992) found increases in post-merger operating performance, while Berger and Humphrey (1992), Piloff (1996), and Berger (1997) did not. Healy, Palepu, and Ruback (1992) found that the post-merger operating performance improves relative to the industry benchmark. Similarly, Liu and Tripe (2001) found that in a majority of cases the merger led to an increase in efficiency. But Akben-Selcuk and Altiok-Yilmaz (2011) found accounting data weakly support the hypothesis that acquirer companies are negatively affected by merger and acquisition. Reda (2013) showed that despite the fact that consolidation had a positive effect on managerial efficiency, banks' profitability remained weak. On the other hand, Long (2015) and Sharma and Ho (2002) found no significant difference in operating performance before and after merger.
In the light of the above review of previous empirical literature the following hypotheses have been framed for this research article.

$\mathrm{H}_{1}$ : There is no significant increase in the operating performance of the acquirer financial institutions following the merger deals.

\section{Data and Methodology}

Altogether 50 financial institutions in Nepal have been merged till July 2013 and they confined to 21 financial institutions through 23 merger deals. The study covers all these merged financial institutions except Butwal Finance (now Synergy Finance after merger), which had not conducted its annual general meeting after merger till the time of collecting data for the study; and hence audited annual reports were not available to extract the data.

This research article is based on secondary data collected from merged financial institutions (FIs), their respective websites and Nepal Rastra Bank. Annual reports of the FIs which contained financial data have been collected by visiting their respective head offices. The t-test has been used to test the significance of null hypotheses and pair t-test has been used to test the differences in the performance of FIs before and after mergers. Statistical Package for Social Sciences (SPSS) program and Microsoft Office Excel have been used to analyze the data.

There are basically two different research methods that are commonly used in measuring the impact of mergers and acquisitions (Gjirja, 2003). One is the operational performance approach, which comprises studies dealing with the link between mergers and the productive efficiency of the banks involved, either measured through accounting data or through the estimation of cost and profit functions. The other approach includes studies 
dealing with the impact of merger announcements on the price of publicly-listed banking companies. This study followed the first approach to analyze the operating performance of mergers. Operating performance of any firm can be measured in term of profit it earned. The relation of the return of the firm to either its sales/revenue or its equity or its assets is known as profitability ratio. The study uses return on assets (ROA), return on equity (ROE), operating profit margin (OPM), net profit margin (NPM), earning yield ratio (EYR) and earnings per share (EPS) to measure profitability.

\section{Results and Discussion}

\section{Profitability ratios of FIs before and after the merger}

Pre- and post- merger accounting data of the acquirers have been analyzed to find out the changes in their financial performance. This attempt has been made to identify whether the expected gains of mergers are actually realized by Nepalese FIs or not. It focuses on accounting measures of profitability using different ratios. These ratios are analyzed in Table 1 through 6.

The table presents return on assets and return on equity before and after the year of the merger. Nepal Bangladesh Bank merged two times during the study period. The first case of merger (with Nepal Bangladesh Finance) is denoted by ' 1 st' and the second case of its merger (with Nepal Srilanka Merchant Finance) is denoted by ' 2 nd.' Similarly, Global Bank merged two times during the study period. The first case of merger (with IME Finance and Lord Buddha Finance) is denoted by ' 1 st' and the second case of its merger (with Social Development Bank and Gulmi Bikas Bank) is denoted by ' 2 nd.'
Table 1 presents the return on asset (ROA) and return on equity (ROE) of merged FIs before and after the merger. Column two presents the average ROA of two years before the merger and column three presents the average ROA of two years after the merger. ROA is calculated dividing the net profit after tax by total assets. The table shows that out of the 22 cases of mergers, ROA has been increased only in 8 cases and decreased in 14 cases. Among the FIs whose ROA has been increased, Nepal Bangladesh Bank $\left(1^{\text {st }}\right)$ stood at the top. There is an increase of ROA of Nepal Bangladesh Bank $\left(1^{\text {st }}\right)$ by more than 27 percent. This big increment in ROA of Nepal Bangladesh Bank $\left(1^{\text {st }}\right)$ is because of its huge negative ROA before merger. Other FIs whose ROA has been increased more than one percent after merger are: Prudential Finance and Laxmi Bank. Vibor Bikash Bank, Shine Development Bank, Global IME Bank, Global Bank and Machhapuchchhre Bank, However, the increment in ROA of these banks after the merger is very nominal and less than 1 percent.

Nepal Bangladesh Bank (2 $\left.{ }^{\text {nd }}\right)$ experienced the highest (11.58 percent) decrease in ROA after merger. Manakamana Development Bank, Infrastructure Development Bank, Royal Merchant Banking and Finance, Annapurna Bikash Bank, Business Development Bank and Kasthamandap Development Bank also experienced large decrease in ROA. Except in three cases, ROA has not increased more than 1 percent after the merger; therefore, it is concluded that merger did not help in increasing ROA of Nepalese FIs. 
Table 1: Return on assets and return on equity of acquirer before and after the merger

\begin{tabular}{|c|c|c|c|c|c|c|c|c|}
\hline \multirow{2}{*}{$\begin{array}{l}\text { Name of financial } \\
\text { institutions }\end{array}$} & \multicolumn{4}{|c|}{ Return on assets (\%) } & \multicolumn{4}{|c|}{ Return on equity (\%) } \\
\hline & $\begin{array}{l}\text { Before } \\
\text { merger }\end{array}$ & $\begin{array}{c}\text { After } \\
\text { merger }\end{array}$ & Differences & Remark & $\begin{array}{l}\text { Before } \\
\text { merger }\end{array}$ & $\begin{array}{l}\text { After } \\
\text { merger }\end{array}$ & Differences & Remark \\
\hline Laxmi Bank & $(0.50)$ & 0.55 & 1.05 & Increased & $(0.62)$ & 2.99 & 3.61 & Increased \\
\hline NB Bank* $\left(1^{\text {st }}\right)$ & (14.99) & 12.19 & 27.18 & Increased & 77.73 & 83.41 & 5.68 & Increased \\
\hline National Finance & 3.04 & 2.68 & -0.36 & Decreased & 12.75 & 11.17 & -1.58 & Decreased \\
\hline NB Bank $\left(2^{\text {nd }}\right)$ & 13.09 & 1.51 & -11.58 & Decreased & 120.95 & 10.63 & -110.32 & Decreased \\
\hline Himchuli Dev Bank & 1.65 & 1.08 & -0.57 & Decreased & 13.96 & 8.22 & -5.74 & Decreased \\
\hline Business Dev Bank & 3.15 & 1.28 & -1.87 & Decreased & 10.70 & 5.75 & -4.95 & Decreased \\
\hline KMDB* & 0.60 & $(0.48)$ & -1.08 & Decreased & 4.95 & $(4.23)$ & -9.18 & Decreased \\
\hline MB* & 0.20 & 0.32 & 0.12 & Increased & 2.32 & 3.38 & 1.06 & Increased \\
\hline Global Bank & 0.85 & 1.01 & 0.16 & Increased & 8.99 & 12.18 & 3.19 & Increased \\
\hline IDB* & 2.56 & $(1.12)$ & -3.68 & Decreased & 11.09 & $(4.77)$ & -15.86 & Decreased \\
\hline $\mathrm{ABB}^{*}$ & 3.41 & 0.71 & -2.7 & Decreased & 7.93 & 2.32 & -5.61 & Decreased \\
\hline Pashupati Dev Bank & 2.16 & 1.95 & -0.21 & Decreased & 6.96 & 7.63 & 0.67 & Increased \\
\hline Vibor Bikash Bank & $(3.78)$ & $(2.88)$ & 0.9 & Increased & $(22.92)$ & $(17.88)$ & 5.04 & Increased \\
\hline Shine Dev Bank & 1.93 & 2.38 & 0.45 & Increased & 15.51 & 21.46 & 5.95 & Increased \\
\hline Prudential Fin Co. & $(2.21)$ & 4.39 & 6.6 & Increased & $(8.53)$ & 14.13 & 22.66 & Increased \\
\hline NIC Bank & 1.89 & 1.51 & -0.38 & Decreased & 21.90 & 15.85 & -6.05 & Decreased \\
\hline Diyalo Bikas Bank & 1.84 & 1.26 & -0.58 & Decreased & 10.53 & 7.42 & -3.11 & Decreased \\
\hline Araniko Dev Bank & 3.19 & 2.50 & -0.69 & Decreased & 9.45 & 9.97 & 0.52 & Increased \\
\hline RMBF* & 1.10 & $(1.80)$ & -2.9 & Decreased & 7.21 & $(13.75)$ & -20.96 & Decreased \\
\hline Global IME Bank & 1.07 & 1.39 & 0.32 & Increased & 11.82 & 14.98 & 3.16 & Increased \\
\hline Prabhu Finance & 1.31 & 0.83 & -0.48 & Decreased & 18.51 & 8.69 & -9.82 & Decreased \\
\hline MKDB* & 1.70 & $(2.78)$ & -4.48 & Decreased & 6.83 & $(25.04)$ & -31.87 & Decreased \\
\hline
\end{tabular}

Source: Annual Reports of FIs

*NB Bank = Nepal Bangladesh Bank; KMDB $=$ Kasthamandap Devlopment Bank; $M B=$ Machhapuchchhre Bank; IDB = Infrastructure Development Bank; $A B B=$ Annapurna Bikas Bank; $R M B F=$ Royal Merchant Banking and Finance; $M K D B=$ Manakamana Development Bank;

The last four columns of Table 1 compare ROE of merged FIs before and after the merger. Column six presents the average ROE of two years before the merger and column seven presents the average ROE of two years after the merger. ROE is calculated dividing the net profit after tax by shareholders' equity. The table shows that out of the 22 cases of mergers, ROE has been increased in 10 cases. On the other hand, ROE has been decreased in 12 merger cases. Among the FIs whose ROE has been increased, Prudential Finance has been able to increase the highest (22.66 percent). Shine Development Bank, Nepal Bangladesh Bank $\left(1^{\text {st }}\right)$, Vibor Bikash Bank, Laxmi Bank, Global Bank, Global IME Bank and Machhpuchchhre Bank stood $2^{\text {nd }}, 3^{\text {rd }}, 4^{\text {th }}, 5^{\text {th }}, 6^{\text {th }}, 7^{\text {th }}, 8^{\text {th }}$, respectively in terms of ROE increment. The decrease in ROE ranges from 110.32 percent to 1.58 percent. Nepal Bangladesh Bank $\left(2^{\text {nd }}\right)$ stood at the top in decreasing ROE after merger with 110.32 percent decrease.

The extensive decrease in ROE of Manakamana Development Bank, Royal Merchant Banking and Finance and Infrastructure Development Bank were due to the negative ROE experienced after 
the merger.

Table 2 shows operating profit margin and net profit margin before and after merger of merged FIs. It is obvious from the table that only in seven cases the operating profit margin of merged FIs has been increased after the merger. decreased in operating profit margin after merger. Thus, it is concluded that majority (67 percent) of the merged FIs have experienced a decreased in operating profit margin.

The last four columns of Table 2 present and compare the net profit margin before and after

Table 2: Operating profit margin and net profit margin of acquirer before and after the merger

\begin{tabular}{|c|c|c|c|c|c|c|c|c|}
\hline \multirow{2}{*}{$\begin{array}{l}\text { Name of financial } \\
\text { institutions }\end{array}$} & \multicolumn{4}{|c|}{ Operating profit margin (\%) } & \multicolumn{4}{|c|}{ Net profit margin $(\%)$} \\
\hline & $\begin{array}{l}\text { Before } \\
\text { merger }\end{array}$ & $\begin{array}{l}\text { After } \\
\text { merger }\end{array}$ & $\begin{array}{l}\text { Differenc- } \\
\text { es }\end{array}$ & Remarks & $\begin{array}{l}\text { Before } \\
\text { merger }\end{array}$ & $\begin{array}{c}\text { After } \\
\text { merger }\end{array}$ & Differences & Remarks \\
\hline Laxmi Bank Ld. & $(89.41)$ & 22.27 & 111.68 & Increased & $(88.40)$ & 17.97 & 106.37 & Increased \\
\hline NB Bank $\left(1^{\text {st }}\right)$ & $(254.05)$ & 38.97 & 293.02 & Increased & $(272.42)$ & 122.49 & 394.91 & Increased \\
\hline National Finance & 52.73 & 65.83 & 13.1 & Increased & 59.46 & 47.70 & -11.76 & Decreased \\
\hline NB Bank $\left(2^{\text {nd }}\right)$ & 56.37 & 44.87 & -11.5 & Decreased & 142.56 & 42.99 & -99.57 & Decreased \\
\hline Himchuli Dev Bank & 59.03 & 45.53 & -13.5 & Decreased & 38.37 & 30.41 & -7.96 & Decreased \\
\hline Business Dev Bank & 76.60 & 39.34 & -37.26 & Decreased & 51.21 & 23.98 & -27.23 & Decreased \\
\hline KMDB & 26.61 & $(15.38)$ & -41.99 & Decreased & 16.92 & $(10.16)$ & -27.08 & Decreased \\
\hline MB & 7.17 & 14.94 & 7.77 & Increased & 5.92 & 9.48 & 3.56 & Increased \\
\hline Global Bank & 24.69 & 33.57 & 8.88 & Increased & 18.56 & 26.69 & 8.13 & Increased \\
\hline IDB & 57.19 & (28.54) & -85.73 & Decreased & 39.88 & $(24.17)$ & -64.05 & Decreased \\
\hline ABB & 37.25 & $(5.52)$ & -42.77 & Decreased & 36.34 & 12.70 & -23.64 & Decreased \\
\hline Pashupati Dev Bank & 45.57 & 26.64 & -18.93 & Decreased & 30.43 & 45.20 & 14.77 & Increased \\
\hline Vibor Bikash Bank & $(271.05)$ & $(1246.50)$ & -975.45 & Decreased & (206.17) & (435.99) & -229.82 & Decreased \\
\hline Shine Dev Bank & 32.52 & 71.72 & 39.2 & Increased & 40.12 & 46.40 & 6.28 & Increased \\
\hline Prudential Finance & $(68.42)$ & (190.49) & -122.07 & Decreased & $(50.25)$ & 132.96 & 183.21 & Increased \\
\hline NIC Bank Ltd. & 63.00 & 59.04 & -3.96 & Decreased & 40.61 & 39.51 & -1.1 & Decreased \\
\hline Diyalo Bikas Bank & 55.54 & 47.44 & -8.10 & Decreased & 37.35 & 30.08 & -7.27 & Decreased \\
\hline Araniko Dev Bank & 63.65 & 25.26 & -38.39 & Decreased & 40.35 & 34.80 & -5.55 & Decreased \\
\hline RMBF & 49.28 & (75.99) & -125.27 & Decreased & 30.88 & (154.53) & -185.41 & Decreased \\
\hline Global IME Bank & 29.94 & 35.58 & 5.64 & Increased & 27.58 & 32.78 & 5.2 & Increased \\
\hline Prabhu Finance & NA & NA & NA & NA & NA & NA & NA & NA \\
\hline MKDB & 18.43 & $(123.23)$ & -141.66 & Decreased & 37.16 & $(70.17)$ & -107.33 & Decreased \\
\hline
\end{tabular}

Source: Annual Reports of FIs

The highest increase was for Nepal Bangladesh Bank ( $1^{\text {st }}$ case) $[293.02$ percent], and the highest decrease was for Vibor Bikash Bank (975.45 percent). The operating profit margin of Laxmi Bank also increased significantly (111.68 percent). But the extensive increases in the operating profit margin of these two FIs are due to the negative operating profit margin before the merger. Fourteen out of twenty one FIs suffered from

merger. It is evidence from the table that net profit margin has been increased in eight cases, while it is decreased in rest of the thirteen cases. The highest rise is in case of Nepal Bangladesh Bank ( $\left.1^{\text {st }}\right)$, which enjoyed an increment by almost 395 percent. Laxmi Bank also achieved a high increased of 183.21 percent of net profit margin.

Vibor Bikash Bank, Royal Merchant Banking and Finance, Manakamana Development Bank, 
Nepal Bangladesh Bank $\left(2^{\text {nd }}\right)$, Infrastructure Development Bank, Business Development Bank, Kasthamandap Development Bank and Annapurna Bikash Bank had to suffer from a big decreased in net profit margin after the merger. As majority of FIs (62 percent) faced huge decreased in the net profit margin after the merger, it is concluded that operating performance of the Nepalese FIs have not improved after merger, rather worsened.

Table 3 exhibits the earning yield and earning per share of merged FIs before and after the merger. As seen in the table, out of the twenty-two merger cases, only nine cases (41 percent) have shown increase in earning yield after their merger. the highest earning yield of 100.85 percent. Thirteen FIs (59 percent) have been observed having decreased in earning yield after merger. The largest decrease in earning yield was faced by Royal Merchant Banking and Finance (19.37 percent). There was marginal decreased in earning yield of Himchuli Development Bank after merger.

Table 3 also includes data on EPS in its last four columns. The table depicts that 55 percent of the merged FIs decreased their EPS after merger while only 45 percent increased their EPS after the merger. Nepal Bangladesh Bank $\left(2^{\text {nd }}\right)$, Manakamana Development Bank, Royal Merchant Banking and Finance and Infrastructure Development Bank had

Table 3: Earning yield and earnings per share of acquirer before and after the merger

\begin{tabular}{|c|c|c|c|c|c|c|c|c|}
\hline \multirow{2}{*}{$\begin{array}{l}\text { Name of financial } \\
\text { institutions }\end{array}$} & \multicolumn{4}{|c|}{ Earning yield (\%) } & \multicolumn{4}{|c|}{ Earnings per share (Rs) } \\
\hline & $\begin{array}{l}\text { Before } \\
\text { merger }\end{array}$ & $\begin{array}{c}\text { After } \\
\text { merger }\end{array}$ & Differences & Remarks & $\begin{array}{l}\text { Before } \\
\text { merger }\end{array}$ & $\begin{array}{l}\text { After } \\
\text { merger }\end{array}$ & Differences & Remarks \\
\hline Laxmi Bank Ld. & 0.30 & 1.37 & 1.07 & Increased & $(0.61)$ & 3.12 & 3.73 & Increased \\
\hline NB Bank (1 $\left.1^{\mathrm{st}}\right)$ & $(76.13)$ & 24.72 & 100.85 & Increased & (198.56) & 98.08 & 296.64 & Increased \\
\hline National Finance & 1.62 & 7.79 & 6.17 & Increased & 17.03 & 14.88 & -2.15 & Decreased \\
\hline NB Bank $\left(2^{\text {nd }}\right)$ & 31.07 & 14.00 & -17.07 & Decreased & 85.46 & 16.70 & -68.76 & Decreased \\
\hline Himchuli Dev Bank & 7.20 & 6.32 & -0.88 & Decreased & 17.42 & 9.01 & -8.41 & Decreased \\
\hline Business Dev Bank & 7.00 & 5.80 & -1.2 & Decreased & 11.28 & 6.49 & -4.79 & Decreased \\
\hline KMDB & 3.66 & $(5.36)$ & -9.02 & Decreased & 5.31 & $(3.81)$ & -9.12 & Decreased \\
\hline MB & 1.00 & 2.14 & 1.14 & Increased & 2.53 & 3.77 & 1.24 & Increased \\
\hline Global Bank & 4.86 & 5.24 & 0.38 & Increased & 9.51 & 13.97 & 4.46 & Increased \\
\hline IDB & 6.91 & $(5.42)$ & -12.33 & Decreased & 12.65 & $(4.74)$ & -17.39 & Decreased \\
\hline $\mathrm{ABB}$ & 8.86 & 2.96 & -5.9 & Decreased & 9.21 & 2.68 & -6.53 & Decreased \\
\hline Pashupati Dev Bank & 5.41 & 9.77 & 4.36 & Increased & 7.32 & 8.02 & 0.7 & Increased \\
\hline Vibor Bikash Bank & (18.98) & $(8.92)$ & 10.06 & Increased & (21.57) & $(11.29)$ & 10.28 & Increased \\
\hline Shine Dev Bank & 7.87 & 6.56 & -1.31 & Decreased & 18.44 & 28.38 & 9.94 & Increased \\
\hline Prudential Finance & $(5.91)$ & 13.31 & 19.22 & Increased & $(6.16)$ & 14.12 & 20.28 & Increased \\
\hline NIC Bank Ltd. & 6.83 & 4.36 & -2.47 & Decreased & 33.83 & 31.88 & -1.95 & Decreased \\
\hline Diyalo Bikas Bank & 13.72 & 6.06 & -7.66 & Decreased & 11.85 & 8.77 & -3.08 & Decreased \\
\hline Araniko Dev Bank & 7.21 & 10.90 & 3.69 & Increased & 10.37 & 10.90 & 0.53 & Increased \\
\hline RMBF & 6.72 & $(12.65)$ & -19.37 & Decreased & 8.64 & (13.91) & -22.55 & Decreased \\
\hline Global IME Bank & 7.27 & 3.42 & -3.85 & Decreased & 13.39 & 17.98 & 4.59 & Increased \\
\hline Prabhu Finance & 12.37 & 6.48 & -5.89 & Decreased & 20.47 & 10.99 & -9.48 & Decreased \\
\hline MKDB & 8.16 & $(9.46)$ & -17.62 & Decreased & 6.28 & $(16.38)$ & -22.66 & Decreased \\
\hline
\end{tabular}

Source: Annual Reports of FIs

Nepal Bangladesh Bank (1 $\left.{ }^{\text {st }}\right)$ was able to increase

to bear extensive decreased in EPS after merger. 
Nepal Bangladesh Bank ( $\left.1^{\text {st }}\right)$ was able to increase the highest EPS by Rs. 296.64, and Nepal Bangladesh Bank $\left(2^{\text {nd }}\right)$ experienced the highest decreased in EPS by Rs 68.76 after the merger. The other FIs which achieved good increased in EPS were Prudential Finance, Vibor Bikash Bank and Shine Development Bank. Pashupati Development Bank and Araniko Development Bank were able to increase their EPS after merger marginally. They increased their EPS by Rs. 0.53 and Rs. 0.70 respectively.

\section{Paired Sample Correlation}

Table 4 presents the paired sample correlation before and after the merger. Out of the six variables, three (50 percent) have negative paired sampled correlation and the rest three (50 percent) has positive correlation.
Table 4: Paired sample correlation before and after merger The figure in the bracket below of each correlation coefficient are significant values.

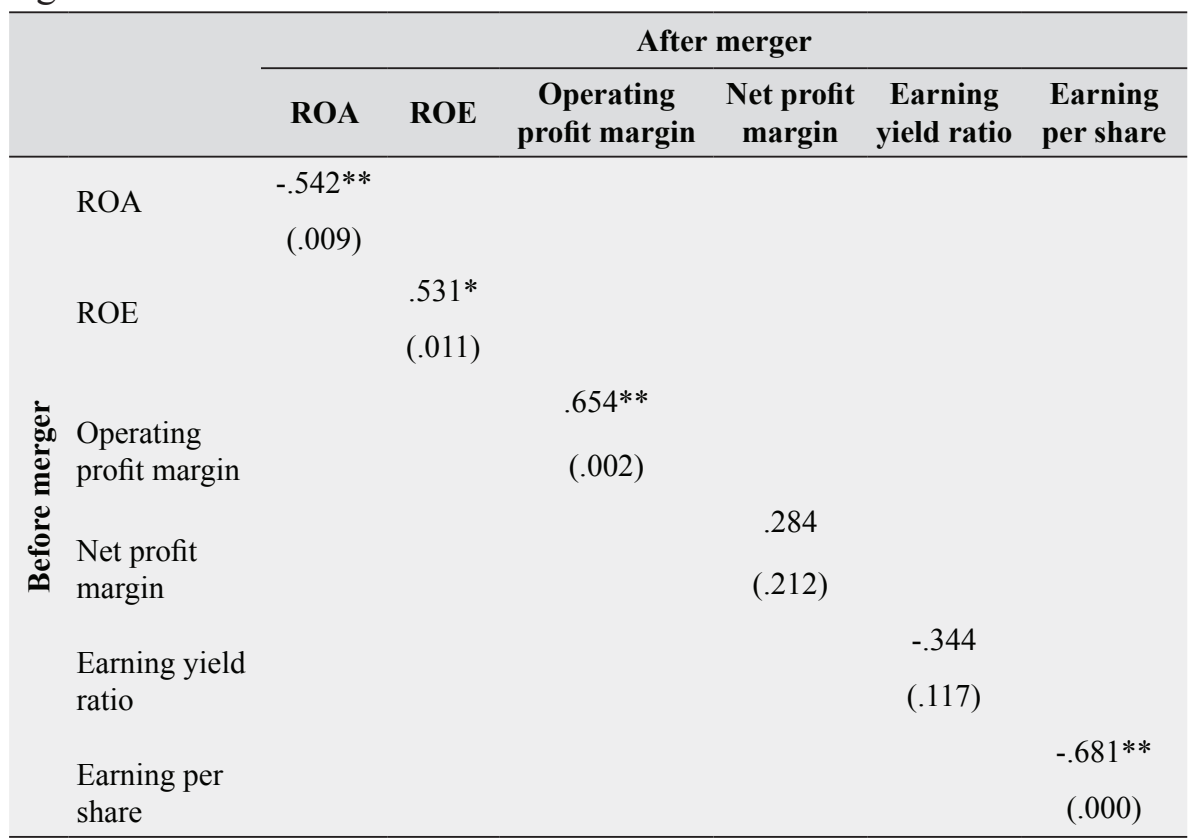

**Significant at 1\% level

*Significant at 5\% level

Among those which are negatively correlated, ROA and EPS are statistically significant at 5 percent level. The significant negative correlation indicates that the measurement changed consistently but negatively across sampled financial institutions.

The earning yield ratio though have negative paired sample correlation is not statistically significant even at 5 percent level. It indicates that the measurement does not change consistently across sampled financial institutions. On the other hand, operating profit margin and ROE have positive paired sampled correlation. Among them operating profit margin is statistically significant at 1 percent level and ROE is statistically significant at 5 percent level. Net profit margin, though has positive paired sampled correlation, is not statistically significant even at 5 percent level. The larger the correlation and it is positive, the less standard error would be in testing the hypothesis that the mean would be different. As this condition is not fulfilled in this case, there is high chance of being standard error in testing the hypothesis.

Table 5 exhibits the paired sample t-test of profitability ratios before and after the merger. It is evidence from the table that out of the six profitability ratios calculated, three ratios $(50$ percent $)$ have been increased while the rest three ratios $(50$ percent) have been decreased after the merger. Among the profitability ratios that have been increased after the merger are ROA, earning yield 
Table 5: Paired sample t-test of profitability ratios before and after merger

\begin{tabular}{|c|c|c|c|c|c|c|}
\hline \multirow[b]{2}{*}{$\begin{array}{l}\text { Profitability } \\
\text { ratio }\end{array}$} & \multicolumn{4}{|c|}{ Mean } & \multirow[b]{2}{*}{ 苞 } & \multirow[b]{2}{*}{ 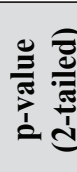 } \\
\hline & $\mathbf{N}$ & 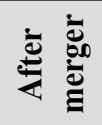 & 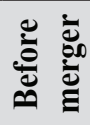 & Differ & & \\
\hline $\begin{array}{l}\text { Return on asset } \\
\text { (ROA) }\end{array}$ & 22 & 1.29 & 1.06 & 24 & .163 & .872 \\
\hline $\begin{array}{l}\text { Return on equity } \\
\text { (ROE) }\end{array}$ & 22 & 7.93 & 15.82 & 78 & -1.461 & .159 \\
\hline $\begin{array}{l}\text { Operating profit } \\
\text { margin }\end{array}$ & 21 & -58.10 & .85 & -58.96 & -1.123 & .271 \\
\hline Net profit m & 21 & .05 & 3.64 & -3.59 & -.131 & .897 \\
\hline $\begin{array}{l}\text { Earning yield } \\
\text { ratio }\end{array}$ & 22 & 4.06 & 2.14 & 1.93 & .378 & .709 \\
\hline $\begin{array}{l}\text { Earning per share } \\
\text { (EPS) }\end{array}$ & 22 & 11.35 & 3.37 & 7.98 & .560 & .581 \\
\hline
\end{tabular}

Source: Annual Reports of FIs

ratio, and EPS; and the profitability ratios that have been decreased are ROE, operating profit margin and net profit margin. But none of the differences in ratios are significant even at 5 percent level of significance. Therefore, the null hypothesis that 'operating performance of merged FIs (acquirers) does not significantly improve after merger' could not be rejected. Hence, it is concluded that profitability of merged FIs does not improve after the merger.

Table 6: Heterogeneity in profitability ratio among merged FIs before and after merger

\begin{tabular}{lccccc}
\hline & & \multicolumn{2}{c}{ Standard deviation } & \multicolumn{2}{c}{ CV in \% } \\
\cline { 3 - 6 } & & $\begin{array}{c}\text { After } \\
\text { merger }\end{array}$ & $\begin{array}{c}\text { Before } \\
\text { merger }\end{array}$ & $\begin{array}{c}\text { After } \\
\text { merger }\end{array}$ & $\begin{array}{c}\text { Before } \\
\text { merger }\end{array}$ \\
\hline ROA & 22 & 2.99 & 4.70 & 231.22 & 444.86 \\
ROE & 22 & 20.34 & 29.34 & 256.39 & 185.50 \\
$\begin{array}{l}\text { Operating } \\
\text { profit margin }\end{array}$ & 21 & 287.38 & 99.16 & -494.59 & 11597.83 \\
$\begin{array}{l}\text { Net profit } \\
\text { margin }\end{array}$ & 21 & 115.78 & 91.82 & 217094.41 & 2521.83 \\
$\begin{array}{l}\text { Earning yield } \\
\text { ratio }\end{array}$ & 22 & 8.60 & 19.54 & 211.57 & 914.32 \\
EPS & 22 & 22.88 & 49.07 & 201.62 & 1457.17 \\
\hline Source: $A n m$ in & & & & & \\
\hline
\end{tabular}

Source: Annual Reports of FIs

Coefficient of variation (CV) is the relative measure of dispersion. Table 6 shows that the CV of four profitability ratios (return on assets, operating profit margin, earning yield ratio and earning per share) has been reduced after the merger; which indicates that the magnitude of heterogeneity in these profitability ratios of merged FIs has been reduced. While the $\mathrm{CV}$ of two profitability ratios (return on equity and net profit margin) has been increased the merger, which indicates that the magnitude of heterogeneity in these ratios of merged FIs has been increased.

\section{Summary and Conclusion}

Merger and acquisition is a very important tool for the expansion of business. It is one of the ways by which business firms attempt to enhance their value. Studies have revealed mixed outcomes as to whether or not mergers and acquisitions do indeed enhance value.

To examine the effects of the merger on operating performance of the merged FIs, this research article analyzes 22 merger cases that were occurred during the period of 2004 to 2013. Hypothesizing that merger would improve performance of FIs in terms of profitability; six different accounting ratios were examined for two year before and two year after their merger. Paired sample t-test was used to compare the operating performance of merged FIs before and after the merger. Out of the six, three ratios (ROA, earning yield ratio and EPS) increased and the rest three ratios (ROE, operating profit margin and net profit margin) decreased after the merger. But none of the differences were significant at 0.05 level. This indicates that the changes in mean value of profitability ratios were not due to the merger leading to the failure of rejection of null hypothesis that 'there is no significant increase in the operating performance of the acquirer FIs following the merger deals.' Thus, the paper concludes that operating performance measured in terms of profitability ratios of FIs does not increase significantly after merger. The result is consistent with results found 
by Berger and Humphrey (1992), Piloff (1996), Berger (1997), Sharma and Ho (2002), Pathak (2013), and Long (2015), who report that there is no significant difference in operating performance before and after merger. But the result contradict with the results of Cornett and Tehranian (1992) and Spindt and Tarhan (1992) who found increases in post-merger operating performance.

\section{Appendix: List of Merged FIs}

This table presents a list of FIs that have been merged till 15 th July 2013. Columns 2 and 3 provide a list of FIs involved in mergers. The names of the new FIs after mergers have been given in Column 4. Column 5 presents the dates of new transactions started by the FIs after completing their mergers. Altogether 50 FIs have been merged and confined to 21 FIs. Nepal Bangladesh Bank and Global IME Banks are repeated in the table because they involved in the activity of mergers in two times. Out of the 23 cases of mergers, 17 cases are the mergers between two FIs while six cases are mergers among three FIs. Among the merged FIs, six are commercial banks, 19 development banks and 25 finance companies. These merger activities reduced the number of FIs by 29.

\begin{tabular}{|c|c|c|c|c|}
\hline $\begin{array}{l}\text { S. } \\
\text { No. }\end{array}$ & \multicolumn{2}{|c|}{ Merger between/among } & New name after merger & $\begin{array}{c}\text { Merged date (transaction } \\
\text { start by new name) }\end{array}$ \\
\hline \multicolumn{5}{|c|}{ Panel A: Mergers before the promulgation of merger bylaw- 2068} \\
\hline 1 & Laxmi Bank & HISEF Finance & Laxmi Bank Ltd. & $2-4-2004$ \\
\hline 2 & Nepal Bangladesh Bank Ltd. & Nepal Bangladesh Finance Co. Ltd. & Nepal Bangladesh Bank Ltd. & 18-9- 2007 \\
\hline 3 & National Finance Ltd. & Narayani Finance Ltd. & Narayani National Fin Ltd. & 3-11- 2009 \\
\hline 4 & Nepal Bangladesh Bank Ltd. & Nepal Srilanka Merchant Finance Ltd. & Nepal Bangladesh Bank Ltd. & 23-1- 2011 \\
\hline \multicolumn{5}{|c|}{ Panel A: Mergers after the promulgation of merger bylaw-2068 } \\
\hline 5 & Himchuli Bikas Bank & Birgunj Finance Ltd. & H \& B Dev Bank Ltd. & $15-6-2011$ \\
\hline 6 & Business Dev Bank & Universal Finance Ltd. & Business Universal Development Bank & $5-3-2012$ \\
\hline 7 & Kasthamandap Dev Bank & Shikhar Finance Ltd. & Kasthamandap Dev Bank & $13-5-2012$ \\
\hline 8 & Machhapuchhre Bank Ltd. & Standard Finance Ltd. & Machhapuchhre Bank Ltd. & $9-7-2012$ \\
\hline 9 & Global Bank Ltd. & $\begin{array}{l}\text { - IME Finance Ltd. } \\
\text { - Lord Buddha Fin Ltd. }\end{array}$ & Global IME Bank Ltd. & 9-7-2012 \\
\hline 10 & Infrastructure Dev Bank & Swastik Merchant Finance Ltd. & Infrastructure Dev Bank & $10-7-2012$ \\
\hline 11 & Annapurna Bikash Bank & Suryadarshan Fin Ltd & Supreme Dev Bank & $13-7-2012$ \\
\hline 12 & Pashupati Dev Bank & Uddhyam Bikash Bank & Axis Dev Bank & $13-7-2012$ \\
\hline 13 & Butwal Finance Ltd. & $\begin{array}{l}\text { - Alpic Everest Fin Ltd. } \\
\text { - CMB Finance Ltd. }\end{array}$ & Synergy Fin Company Ltd. & $6-12-2012$ \\
\hline 14 & Vibor Bikash Bank Ltd. & Bhajuratna Fin and Saving Company Ltd. & Vibor Bikash Bank & 2-9-2012 \\
\hline 15 & Shine Bikash Bank Ltd. & Reshunga Bikash Bank Ltd. & Shine Reshunga Dev Bank Ltd. & $17-3-2013$ \\
\hline 16 & Prudential Fin Co. Ltd. & Gorkha Finance Ltd. & Prudential Finance Co. Ltd. & $18-3-2013$ \\
\hline 17 & NIC Bank Ltd. & Bank of Asia Nepal Ltd. & NIC Asia Bank Ltd. & $30-6-2013$ \\
\hline 18 & Diyalo Bikash Bank Ltd. & Professional Bikash Bank Ltd. & Professional Diyalo Bikash Bank & $9-7-2013$ \\
\hline 19 & Araniko Dev Bank Ltd. & Surya Dev Bank Ltd. & Araniko Dev Bank & $14-7-2013$ \\
\hline 20 & $\begin{array}{l}\text { Royal Merchant Banking } \\
\text { Finance Ltd. }\end{array}$ & $\begin{array}{l}\text { - Rara Bikash Bank } \\
\text { - Api Finance Ltd. }\end{array}$ & Apex Dev Bank Ltd. & NA \\
\hline 21 & Global IME Bank Ltd. & $\begin{array}{l}\text { - Social Dev Bank Ltd. } \\
\text { - Gulmi Bikash Bank }\end{array}$ & Global IME Bank Ltd. & $14-7-2013$ \\
\hline 22 & Prabhu Finance Ltd. & $\begin{array}{l}\text {-Sambridhi Bikash Bank Ltd. } \\
\text {-Baibhav Finance Ltd. }\end{array}$ & Prabhu Bikash Bank Ltd. & NA \\
\hline 23 & $\begin{array}{l}\text { Manakamana Development } \\
\text { Bank }\end{array}$ & $\begin{array}{l}\text { - Yeti Finance Ltd. } \\
\text { - Valley Finance Ltd. }\end{array}$ & Yeti Development Bank Ltd. & $15-7-2013$ \\
\hline
\end{tabular}

Source: Nepal Rastra Bank and respective offices of FIS

\section{REFERENCES}

Akben-Selcuk, E., \& Altiok-Yilmaz, A. (2011). The impact of mergers and acquisitions on acquirer performance: evidence from Turkey. Business and Economic Journal 2, 12-19.

Avkiran, N. K. (1999). The Evidence on efficiency gains: The role of mergers and the benefits to the public. Journal of Banking and Finance,
23, 991-1013.

Berger, A. N. (1997). The efficiency effects of bank mergers and acquisitions: A preliminary look at the 1990s data. In Y. Amihud, and G. Miller (Eds.), Mergers of Financial Institutions (na).

Homewood, IL: Business One-Irwin.

Berger, A. N., \& Humphrey, D. B. (1992). Megamergers 
in banking and the use of cost efficiency as an antitrust defense. Antitrust Bulletin, 37, 541600.

Berger, A. N., \& Humphrey, D. B. (1997). Efficiency of financial institutions: international survey and directions for future research. European Journal of Operational Research, 98, 175-212.

Bruner, R. (2002). Does M \& A pay? A survey of evidence for the decision maker. The Journal of Applied Finance, 12(1), 1-34.

Copeland, T. E., Weston, J. F., Shastri, K., \& Katz, J. M. (2011). Financial theory and corporate policy $\left(4^{\text {th }}\right.$ ed. $)$. Delhi: Dorling Kindersley.

Cornett, M. M., \& Tehranian, H. (1992). Changes in corporate performance associated with bank acquisitions. Journal of Financial Economics, 31, 211-234.

Coyle, B. ( 2000). Mergers and acquisition (2 ${ }^{\text {nd }}$ ed.). Canterbury: CIB Publishing.

DePamphilis, D. M. (2008). Mergers, acquisitions and other restructuring activities ( $4^{\text {th }}$ ed.). Burlington: Academic Press.

Dobbs, R., Goedhart, M., \& Suonio, H. (2006). Are companies getting better at M \& A ? McKinsey Quarterly, December Economics, 7, 101-116.

Gjirja, M. (2003). Assessing the efficiency effects of bank mergers in Sweden: A panel-based stochastic frontier analysis. Paper presented at the Applied Business Research Conference in Acapulco, Mexico.

Healy, P. M., Palepu, K. G., \& Ruback, R. S. (1992). Does corporate performance improve after takeovers ? Journal of Financial Economics, 31, 135-175.

Jayadev, M., \& Sensarma, R. (2007). Mergers and acquisitions in PSU banks. (A research report). Submitted to the Indian Institute of Banking and Finance (IIBF), Mumbai.

Kwan, S. H., \& Wilcox, J. A. (1999). Hidden cost reductions in bank mergers: Accounting for more productive banks. Proceedings of the 35th Annual Conference on Bank Structure and Competition, Federal Reserve Bank of Chicago, May 5, Chicago.

Liu, B., \& Tripe, D. W. (December 2001). New

Hari Prasad Pathak is an Associate Professor in Finance at Prithvi Narayan Campus, Pokhara. He has more than 21 years of experience in teaching and research and published more than a dozen research papers in various journals. He was
Zealand bank mergers and efficiency gains. Paper presented at the $14^{\text {th }}$ Annual Australian Finance and Banking Conference, Sydney.

Long, P.H. (June 2015). Merger and acquisitions in the Czech banking sector-impact of bank mergers on the efficiency of banks. Journal of Advanced Management Science, 3(2), 86-92.

Nepal Economic Forum. (22 June 2010). Appreciating mergers and acquisition. Proceedings Report.

Osae, W. K. (2010). A value assessment of mergers and acquisitions in the South African Mining Industry. (Unpublished Master's dissertation). Department of Engineering, University of Pretoria.

Pathak, H. P. (2013). Announcement effects of mergers in Nepalese financial institutions (Unpublished M. Phil. Thesis). Office of the Dean, Faculty of Management, Tribhuvan University.

Pillof, S. J. (1996). Performance changes and shareholder wealth creation associated with mergers of publicly traded banking institutions. Journal of Money Credit and Banking, 28(2), 294-310.

Ramani, V. (2012). Corporate mergers and acquisitions: Legal, accounting and strategic issues. PHILICA.COM Article number 325.

Reda, M. (2013). The effect of mergers and acquisitions on bank efficiency: Evidence from bank consolidatin in Egypt. Economic Research Forum. Working Paper Series. Working Paper No. 770.

Sharma, D. S., \& Ho, J. (2002). The impact of acquisitions on operating performance: some Australian evidence. Journal of Business Finance and Accounting, 29, 155-200.

Sherman, A. J., \& Hart, M. A. (2006). Merger and acquisitions from A to Z. New York: AMACOM.

Spindt, P. A., \& Tarhan, V. (1992.). Are there synergies in bank mergers? Tulane University Working Paper.

Weston, J. F., Mitchell, M. L., \& Mulherin, J. H. (2004). Takeovers, restructuring, and corporate governance. New York: Pearsons Education Ltd.

awarded a M.Phil. degree in 2014. He is also a Ph.D. scholar of Tribhuvan University, Nepal. His area of interests includes VAT, credit management, and mergers and acquisitions.

e-mail: haripathak75@gmail.com 